\title{
Proteolytic activity of Enterococcus faecalis VB63F for reduction of allergenicity of bovine milk proteins
}

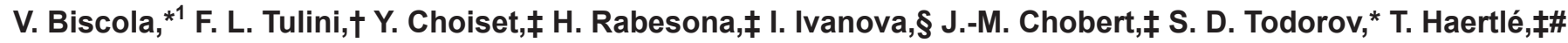 \\ and B. D. G. M. Franco* \\ ${ }^{*}$ Food Research Center, Department of Food and Experimental Nutrition, Faculty of Pharmaceutical Sciences, University of São Paulo, 580, \\ Professor Lineu Prestes, 13 B, Sao Paulo, SP, 05508-000, Brazil \\ †Department of Food Engineering, Faculty of Animal Sciences and Food Engineering, University of São Paulo, 225, Duque de Caxias Norte, \\ Avenue, Pirassununga, SP, 13635-900, Brazil \\ fUR 1268 Biopolymères Interactions Assemblages, INRA, Protein Functions and Interactions Research Team, B.P. 71627, 44316, \\ Nantes Cedex 03, France \\ §Department of General and Applied Microbiology, Faculty of Biology, Sofia University “St. Kliment Ohridski," Dragan Tzankov Blvd 8, 1164 Sofia, \\ Bulgaria \\ \#Department of Animal Nutrition and Feed Management, Poznan University of Life Sciences, ul. Wołyńska 33, 60-637 Poznan, Poland
}

\section{ABSTRACT}

With the aim of screening proteolytic strains of lactic acid bacteria to evaluate their potential for the reduction of allergenicity of the major bovine milk proteins, we isolated a new proteolytic strain of Enterococcus faecalis (Ent. faecalis VB63F) from raw bovine milk. The proteases produced by this strain had strong activity against caseins $\left(\alpha_{\mathrm{S1}^{-}}, \alpha_{\mathrm{S} 2^{-}}\right.$, and $\beta$-casein $)$, in both skim milk and sodium caseinate. However, only partial hydrolysis of whey proteins was observed. Proteolysis of Na-caseinate and whey proteins, observed after sodium dodecyl sulfate-PAGE, was confirmed by analysis of peptide profiles by reversed-phase HPLC. Inhibition of proteolysis with EDTA indicated that the proteases produced by Ent. faecalis VB63F belonged to the group of metalloproteases. The optimal conditions for their activity were $42^{\circ} \mathrm{C}$ and $\mathrm{pH}$ 6.5. The majority of assessed virulence genes were absent in Ent. faecalis VB63F. The obtained results suggest that Ent. faecalis VB63F could be efficient in reducing the immunoreactivity of bovine milk proteins.

Key words: protein hydrolysis, milk allergy, casein, whey protein

\section{INTRODUCTION}

Cow milk allergy (CMA) affects approximately $2.5 \%$ of children under $3 \mathrm{yr}$ of age and represents $9 \%$ of all diagnosed cases of food allergies. It is estimated that about $80 \%$ of the allergic children overcome the problem in the adulthood. However, $20 \%$ of these patients remain allergic for life (Cocco et al., 2003; Gaudin et

Received February 16, 2016.

Accepted March 22, 2016.

${ }^{1}$ Corresponding author: vbiscola@usp.br al., 2008). Recent studies indicate that the frequency of CMA persistence to older ages is increasing (Passalacqua et al., 2012; Feldman and Bird, 2014). The symptoms of CMA vary among patients and include gastrointestinal and skin problems, asthma, rhinitis, and, in extreme cases, anaphylaxis (Gaudin et al., 2008; $\mathrm{Bu}$ et al., 2013). Cow milk allergy is an immunological reaction related to the recognition and binding of IgE to specific epitopes in milk proteins (Cocco et al., 2003; Claeys et al., 2013). $\beta$-Lactoglobulin is the main milk protein recognized by $\mathrm{IgE}$, accounting for $80 \%$ of allergy cases and identified as the main agent of CMA development (Pescuma et al., 2012; Claeys et al., 2013). However, milk caseins $\left(\alpha_{\mathrm{S}^{-}}, \alpha_{\mathrm{S} 2^{-}}, \beta-\mathrm{CN}\right)$ also play a relevant role in the development of CMA (Docena et al., 1996; Natale et al., 2004; Restani et al., 2009; Bu et al., 2010; El-Ghaish et al., 2010), and the linear epitopes present in this protein fraction of milk are related to the persistence of allergy and the occurrence of more severe symptoms (Vila et al., 2001).

Several strategies and technological approaches have been undertaken to reduce bovine milk allergenicity. Enzymatic and heating treatments have been used to induce modifications in the proteins' main epitopes and reduce their capability to bind to specific $\operatorname{IgE}$ (Taheri-Kafrani et al., 2009). Also, the combination of microwave irradiation and enzymatic proteolysis has yielded good results in reduction of immunoreactivity of $\beta$-LG (El Mecherfi et al., 2011). High temperatures can induce structural modifications in conformational epitopes, leading to loss of their binding capability. However, linear epitopes are unaffected by these modifications and remain able to bind to specific IgE. Because milk proteins have both conformational and linear epitopes, heating treatments exert a small effect on the immunoreactivity of milk, mainly in its casein fraction (Restani et al., 2009; Bu et al., 2013). 
Another alternative to reduce the immunoreactivity of milk proteins is the reduction of the molecular mass of the principal milk allergens and cleavage of the allergic epitopes by hydrolysis during microbial fermentation (Claeys et al., 2013). Milk is poor in free amino acids; therefore, microbial proteolytic enzymes play an important role in the generation of the EAA required for the growth of microorganisms in this food matrix (Lozo et al., 2011).

Lactic acid bacteria (LAB) are part of the microbiota of milk and possess a complex proteolytic metabolism, by means of proteinases, peptidases, and transport enzymes. Some strains of LAB produce proteases able to hydrolyze the epitopes of the proteins responsible for the development of CMA, reducing their allergenic potential (Bu et al., 2010; El-Ghaish et al., 2011; Pescuma et al., 2015). Several authors have reported that the treatment of caseins and whey protein fractions with proteolytic LAB can reduce the antigenic response of these proteins and suggest the inclusion of such hydrolysates in the manufacture of hypoallergenic formulations and dairy products (Bertrand-Harb et al., 2003; Cocco et al., 2003; Peñas et al., 2006; Pescuma et al., 2010, 2011).

Interest is increasing in the study of new LAB applicable in the development of novel probiotic and functional foods (Mozzi et al., 2013; Pescuma et al., 2015). Considering that functional foods are those that, in addition to their nutritional requirements, are beneficial for health (Koch et al., 2014), hypoallergenic fermented dairy products can be included in this group of foods (Pescuma et al., 2011). However, the reduction of immunoreactivity of milk proteins by the use of LAB depends on the strain and the process conditions (Kleber et al., 2006; Bu et al., 2010). This fact has stimulated more research on new proteolytic LAB strains able to hydrolyze the milk proteins responsible for CMA for application in the design of novel hypoallergenic dairy products (El-Ghaish et al., 2011). The aim of this study was to screen for novel proteolytic LAB strains in raw bovine milk, targeting caseins $\left(\alpha_{\mathrm{S1}^{-}}, \alpha_{\mathrm{S}_{2}}\right.$, and $\beta-\mathrm{CN})$ and whey proteins, to identify the most promising strains, optimize the proteolytic activity, verify the absence of virulence factors, and evaluate the potential application in reduction of the allergenicity of bovine milk proteins.

\section{MATERIALS AND METHODS}

\section{Isolation of Proteolytic LAB}

Lactic acid bacteria were isolated from raw bovine milk samples obtained from a local farm in Nantes,
France. For isolation of proteolytic LAB, milk samples were submitted to serial 10 -fold dilutions in $0.85 \%$ (wt/ vol) $\mathrm{NaCl}$ solution and plated onto de Man, Rogosa and Sharpe (MRS) agar (Oxoid, Basingstoke, UK) and M17 agar (Oxoid), supplemented with 20\% UHT skim milk (Délisse, Abbeville, France), as described by Ahmadova et al. (2011). Plates were incubated at $30^{\circ} \mathrm{C}$, $37^{\circ} \mathrm{C}$, or $42^{\circ} \mathrm{C}$ for $48 \mathrm{~h}$, and examined for the presence of isolated colonies presenting clear surrounding halos, indicating potential production of proteolytic enzymes (Pailin et al., 2001). Colonies presenting these features were selected, transferred to M17 broth, streaked on M17 agar to obtain pure cultures, and then submitted to Gram staining and catalase test. Gram-positive and catalase-negative isolates were considered as LAB and stored at $-80^{\circ} \mathrm{C}$ in M17 broth, containing $20 \%$ (wt/ vol) glycerol (Sigma-Aldrich, Munich, Germany) as cryoprotector, for further characterization. Before use, the isolates were reactivated twice in UHT skim milk and then once in M17 broth.

\section{Confirmation of Proteolytic Activity}

Confirmation of proteolytic activity was performed by fermentation of UHT skim milk, according to ElGhaish et al. (2010). Briefly, overnight cultures of each isolate in M17 broth were centrifuged at 10,000 $\times g$ for $5 \mathrm{~min}$ at $4^{\circ} \mathrm{C}$, and the pellets were resuspended in sterile Na-phosphate buffer (100 mM, pH 7.0). The suspensions were inoculated $(5 \% \mathrm{vol} / \mathrm{vol})$ in UHT skim milk and incubated at $37^{\circ} \mathrm{C}$ for $24 \mathrm{~h}$ (test samples). Resulting milk proteins and peptides were separated by SDS-PAGE, carried out according to Laemmli (1970). Controls consisted of UHT skim milk added to the same volume of sterile M17 broth. Enterococcus faecalis HH22 (El-Ghaish et al., 2010) was used as a positive control of proteolytic activity. The occurrence and extension of proteolysis was confirmed comparing the SDS-PAGE band profiles of test and control samples.

The SDS-PAGE was carried out in a vertical slab electrophoresis cell (Mini Protean 3 System, BioRad, Hercules, CA). The samples were diluted (1:1) in a solubilization buffer $[50 \mathrm{~m} M$ Tris-HCl (Euromedex, Souffelweyersheim, France), pH 6.8, 4\% SDS (Sigma-Aldrich), 20\% glycerol, 3\% 2-mercaptoethanol (Sigma-Aldrich), and $0.07 \%$ bromophenol blue (Sigma-Aldrich)] and heated at $60^{\circ} \mathrm{C}$ for $5 \mathrm{~min}$. Heated samples were centrifuged $\left(10,000 \times g\right.$ for $5 \mathrm{~min}$ at $\left.25^{\circ} \mathrm{C}\right)$ and the supernatant was further diluted in the solubilization buffer $(1: 5, \mathrm{vol} / \mathrm{vol})$ to achieve a convenient concentration of proteins. This mixture was heated at $100^{\circ} \mathrm{C}$ for $3 \mathrm{~min}$, and loaded onto $12 \%$ polyacrylamide gels; the proteins were separated by electrophoresis in the following con- 
ditions: $10 \mathrm{~mA}$ on the stacking gel $(7.8 \%$ acrylamide) and $20 \mathrm{~mA}$ on the separation gel (12\% acrylamide). Migration buffer was composed of $50 \mathrm{~m} M$ Tris, 0.384 $M$ glycine (Euromedex), and 0.1\% SDS. After electrophoresis, the gels were stained with Coomassie Brilliant Blue R250 overnight, destained for approximately 3 $\mathrm{h}$ with a solution composed of $30 \%$ ( $\mathrm{vol} / \mathrm{vol}$ ) ethanol (Carlo Erba Reagents, Peypin, France) and 5\% (vol/ vol) acetic acid (Carlo Erba Reagents) and scanned with an Image Scanner III (GE Healthcare, Piscataway, NJ) for visualization of the bands.

\section{Analysis of the Proteolytic LAB Strains}

The 51 isolates, which had confirmed proteolytic activity against milk proteins, were submitted to random amplification of polymorphic DNA (RAPD)-PCR analysis for determination of similarity, using the primers E1 and E2 (Kirilov et al., 2011) and M13 (Rossetti and Giraffa, 2005), as described in Table 1. Total DNA of each isolate was extracted using the Bacterial DNA commercial kit (Omega Bio-Tek, Norcross, GA), and the concentration of DNA was measured by determining the ratio between the absorbance (A) at 260 and $280 \mathrm{~nm}\left(\mathrm{~A}_{260} / \mathrm{A}_{280}\right)$, using a spectrophotometer (BioPhotometer, Eppendorf, Westbury, NY).

Amplifications of DNA were carried out in reaction mixtures of $25 \mu \mathrm{L}$ (final volume) containing $40 \mathrm{ng}$ of DNA template, $0.2 \mu \mathrm{mol}$ of primer, and $4.4 \mu \mathrm{L}$ of $5 \times$ BioAmp master mix (BioFidal, Lyon, France). The amplification program for primers E1 and E2 consisted of a first denaturation step at $94^{\circ} \mathrm{C}$ for 5 min, 4 cycles of $94^{\circ} \mathrm{C}$ for $45 \mathrm{~s}$ (denaturation), $30^{\circ} \mathrm{C}$ for $2 \mathrm{~min}$ (annealing), and $72^{\circ} \mathrm{C}$ for $30 \mathrm{~s}$ (extension), followed by 30 cycles of $94^{\circ} \mathrm{C}$ for $5 \mathrm{~s}$ (denaturation), $36^{\circ} \mathrm{C}$ for $30 \mathrm{~s}$ (annealing), and $72^{\circ} \mathrm{C}$ for $40 \mathrm{~s}$ (extension), with a final extension step at $72^{\circ} \mathrm{C}$ for $10 \mathrm{~min}$. The amplification program for primer M13 consisted of a first denaturation step at $94^{\circ} \mathrm{C}$ for $2 \mathrm{~min}$, followed by 40 cycles of $94^{\circ} \mathrm{C}$ for 30 $\mathrm{s}$ (denaturation), $42^{\circ} \mathrm{C}$ for $20 \mathrm{~s}$ (annealing), and $72^{\circ} \mathrm{C}$ for 2 min (extension), with a final extension step at $72^{\circ} \mathrm{C}$ for $10 \mathrm{~min}$. All amplifications were performed in a Touchgene gradient thermocycler (Techne, Stone, UK).

The amplified products were separated by electrophoresis at $100 \mathrm{~V}$ on $1.5 \%$ (wt/vol) agarose gels with ethidium bromide $(0.5 \mathrm{mg} / \mathrm{mL}$; Sigma-Aldrich), in $0.5 \times$ Tris-acetate-EDTA buffer ( $40 \mathrm{~m} M$ Tris-acetate, $1 \mathrm{mM}$ EDTA, pH 8.0; Sigma-Aldrich) and observed under UV light. The strains presenting different profiles by RAPD-PCR analysis were submitted to identification through 16S rDNA amplification.

\section{Identification of Proteolytic Strains}

Total DNA of proteolytic LAB strains was used as template for amplification of the 16S rDNA gene by PCR with universal primers fD1 and rD1 (Table 1), according to Weisburg et al. (1991). The reaction mixture $(50-\mu \mathrm{L}$ final volume) was composed of $40 \mathrm{ng}$ of DNA template, $0.5 \mu \mathrm{mol}$ of each primer, and $8.6 \mu \mathrm{L}$ of $5 \times$ BioAmp master mix (BioFidal). The amplification program included a first denaturation step at $95^{\circ} \mathrm{C}$ for $2 \mathrm{~min}$, followed by 40 cycles of: $95^{\circ} \mathrm{C}$ for $30 \mathrm{~s}$ (denaturation), $45^{\circ} \mathrm{C}$ for $30 \mathrm{~s}$ (annealing), and $72^{\circ} \mathrm{C}$ for 30 s (extension) with a final extension step at $72^{\circ} \mathrm{C}$ for 7 min. Amplification was done in a Touchgene gradient

Table 1. Primers used in this study

\begin{tabular}{|c|c|c|}
\hline Target & PCR primer $\left(5^{\prime}-3^{\prime}\right)$ & Reference \\
\hline $\mathrm{RAPD}^{1}$ & $\begin{array}{l}\text { E1: TCACGCTGCA } \\
\text { E2: TCACGCTGCA }\end{array}$ & Kirilov et al. (2011) \\
\hline & M13: GAGGGTGGCGGTTCT & Rossetti and Giraffa (2005) \\
\hline $16 \mathrm{~S}$ rDNA & $\begin{array}{l}\text { fD1: AGAGTTTGATCCTGGCTCAG } \\
\text { rD1: TAAGGAGGTGATCCAGGC }\end{array}$ & Weisburg et al. (1991) \\
\hline asa1 & $\begin{array}{l}\text { ASA 11: GCACGCTATTACGAACTATGA } \\
\text { ASA 12: TAAGAAAGAACATCACCACGA }\end{array}$ & Vankerckhoven et al. (2004) \\
\hline ace & $\begin{array}{l}\text { ACE F: GAATTGAGCAAAAGTTCAATCG } \\
\text { ACE R: GTCTGTCTTTTCACTTGTTTC }\end{array}$ & Ben Omar et al. (2004) \\
\hline efaAfs & $\begin{array}{l}\text { TE5: GACAGACCCTCACGAATA } \\
\text { TE6: AGTTCATCATGCTGTAGTA }\end{array}$ & Eaton and Gasson (2001) \\
\hline$e s p$ & $\begin{array}{l}\text { ESP 14F: AGATTTCATCTTTGATTCTTG4 } \\
\text { ESP 12R: AATTGATTCTTTAGCATCTGG }\end{array}$ & Vankerckhoven et al. (2004) \\
\hline cylA & $\begin{array}{l}\text { CYT I: ACTCGGGGATTGATAGGC } \\
\text { CYT IIb: GCTGCTAAAGCTGCGCTT }\end{array}$ & Vankerckhoven et al. (2004) \\
\hline cylB & $\begin{array}{l}\text { cylB1: AAGTACACTAGTAGAACTAAGGGA } \\
\text { cylB2: ACAGTGAACGATATAACTCGCTATT }\end{array}$ & Semedo et al. (2003) \\
\hline gelE & $\begin{array}{l}\text { GEL 11: TATGACAATGCTTTTTGGGAT } \\
\text { GEL12: AGATGCACCCGAAATAATATA }\end{array}$ & Vankerckhoven et al. (2004) \\
\hline
\end{tabular}

${ }^{1}$ Rapid amplification of polymorphic DNA. 
thermocycler, and the sequencing of the amplified fragments was carried out by MilleGen sequencing service (Labège, France). The obtained sequences were compared with those available in GenBank database, using the Basic Local Alignment Search Tool (BLAST) at the National Center of Biotechnology Information website (http://www.ncbi.nlm.nih.gov/).

\section{Investigation of Virulence Genes}

The safety of the 9 identified proteolytic LAB strains for their application in food was assessed by investigation of the presence of virulence genes asa1 (aggregation substance), ace (adhesin of collagen protein), esp (enterococcal surface protein), efaAfs (cell wall adhesin), cylA/B (cytolysins), and gelE (gelatinase). Tests were carried out by PCR using the specific primers described in Table 1 . The reaction mixtures $(25-\mu \mathrm{L}$ final volume) contained $40 \mathrm{ng}$ of DNA template, $0.2 \mu \mathrm{mol}$ of each primer, and $4.4 \mu \mathrm{L}$ of $5 \times$ BioAmp master mix. The amplifications were carried out in a Touchgene gradient thermocycler as follows: $94^{\circ} \mathrm{C}$ for $15 \mathrm{~min}$ (first denaturation step), 35 cycles of $94^{\circ} \mathrm{C}$ for 1 min (denaturation), annealing step for $1 \mathrm{~min}$ at $58^{\circ} \mathrm{C}(\mathrm{cylA}), 52^{\circ} \mathrm{C}(\mathrm{cylB})$, $54^{\circ} \mathrm{C}$ (efaAfs), $45^{\circ} \mathrm{C}$ (gelE), and $56^{\circ} \mathrm{C}$ (asa1, ace, and $e s p$ ), and extension at $72^{\circ} \mathrm{C}$ for $1 \mathrm{~min}$, with a final extension step at $72^{\circ} \mathrm{C}$ for $5 \mathrm{~min}$. The amplified fragments were analyzed by electrophoresis at $100 \mathrm{~V}$ in $1 \%$ (wt/ vol) agarose gels with ethidium bromide $(0.5 \mathrm{mg} / \mathrm{mL})$, in $0.5 \times$ Tris-acetate-EDTA buffer $\mathrm{pH} 8.0$ and observation under UV light. Genomic DNA from Enterococcus faecalis MMH594, harboring the target virulence genes, was used as positive control (Shankar et al., 2001).

\section{Proteolytic Activity in a Nonproliferative Cell System}

The proteolytic LAB strains were tested for the capability to hydrolyze $\mathrm{Na}$-caseinate and whey proteins in the nonproliferative cell system described by El-Ghaish et al. (2010). Overnight cultures of each proteolytic LAB strains were obtained in M17 broth. The cells were removed from the medium by centrifugation $(10,000 \times$ g, $5 \mathrm{~min}, 4^{\circ} \mathrm{C}$ ) and resuspended in the same volume of sterile saline solution $(0.85 \% \mathrm{NaCl}$, wt/vol $)$. Proteinase production was induced by surface-plating the suspensions $(200 \mu \mathrm{L})$ on milk-citrate agar, composed of UHT skim milk (44\%, vol/vol), Na-citrate $(0.8 \%$, wt/ vol; Sigma-Aldrich), yeast extract (0.1\% wt/vol; Fluka, Sigma-Aldrich), glucose (0.5\%, wt/vol; Sigma-Aldrich), and agar (1.5\%, wt/vol; Fluka, Sigma-Aldrich; Fira et al., 2001). After incubation at $37^{\circ} \mathrm{C}$ for $24 \mathrm{~h}$, sterile saline solution $(0.8 \% \mathrm{NaCl})$, supplemented with $10 \mathrm{mM}$ $\mathrm{CaCl}_{2}$, was added to the plates and the cells were col- lected with the help of a Drigalski loop. The cell suspensions were washed twice in the same diluent $(10,000$ $\left.\times g, 5 \mathrm{~min}, 4^{\circ} \mathrm{C}\right)$ and resuspended in Na-phosphate buffer $(100 \mathrm{~m} M, \mathrm{pH} 7.0)$ to a final optical density at $600 \mathrm{~nm}$ of 20.

Proteolytic activity was tested by mixing the cell suspensions $(1: 1, \mathrm{vol} / \mathrm{vol})$ with purified fractions of milk proteins (Na-caseinate or denatured whey proteins, all of analytical grade and obtained at a laboratory scale after precipitation at $\mathrm{pH} 4.6$ ). Both Na-caseinate and whey proteins were solubilized in Na-phosphate buffer (100 mM, pH 7.0) and brought to a concentration of 12 $\mathrm{mg} / \mathrm{mL}$. The solution of whey proteins was subjected to a denaturation step by heating at $80^{\circ} \mathrm{C}$ for $30 \mathrm{~min}$, before mixing with LAB cells. The mixtures of LAB cells and protein substrates were incubated at $37^{\circ} \mathrm{C}$ for $24 \mathrm{~h}$ and centrifuged $\left(10,000 \times g, 5 \mathrm{~min}, 4^{\circ} \mathrm{C}\right)$, and the supernatants were analyzed by SDS-PAGE. The LAB strain able to cause the highest reduction in the intensity of the color of the bands, representing proteins from Na-caseinate and whey fractions, was considered to display the best proteolytic activity and selected for further experiments.

The protein hydrolysis assays performed in nonproliferative cell system included negative controls, prepared by mixing the protein substrates with Na-phosphate buffer in a 1:1 (vol/vol) ratio and incubating in the same conditions as test samples.

\section{Effect of Temperature and $\mathrm{pH}$ on Proteolytic Activity}

The tests were performed in the nonproliferative cell system, using either Na-caseinate or denatured whey proteins as substrates. The influence of temperature on proteolytic activity was evaluated by mixing the cell suspension of the selected LAB strain with the substrates in a $1: 1$ ( $\mathrm{vol} / \mathrm{vol}$ ) ratio and incubating at $30^{\circ} \mathrm{C}, 37^{\circ} \mathrm{C}$, or $42^{\circ} \mathrm{C}$ for $24 \mathrm{~h}$. To determine the effect of $\mathrm{pH}$, the cell suspension was prepared in Na-phosphate buffer $(100 \mathrm{~m} M)$ with different $\mathrm{pH}$ values $(6.0,6.5$, and 7.0) and mixed with the substrates (1:1, vol/vol), solubilized in Na-phosphate buffer $(100 \mathrm{mM})$ at the corresponding $\mathrm{pH}$. The mixtures were incubated at $37^{\circ} \mathrm{C}$ for $24 \mathrm{~h}$. Protein hydrolysis and peptide formation were observed submitting the mixtures to SDS-PAGE, as described in the section Confirmation of Proteolytic Activity.

\section{Effect of Inhibitors on Proteolytic Activity}

The type of proteinase produced by the selected LAB strains was determined by testing the effect of protease inhibitors on proteolytic activity in the nonproliferative 
cell system. The tests were carried out under the optimal conditions of $\mathrm{pH}$ and temperature for the proteolytic activities determined as described in the subsection Effect of Temperature and $\mathrm{pH}$ on Proteolytic Activity $\left(42^{\circ} \mathrm{C}, \mathrm{pH} 6.5\right)$ and using Na-caseinate or denatured whey proteins as substrates. The cell suspensions were prepared in Na-phosphate buffer $(100 \mathrm{~m} M$, pH 6.5) and added of different protease inhibitors: EDTA (inhibitor of metalloproteases); iodoacetic acid (inhibitor of cysteine proteases); or 4-(2-aminoethyl)-benzenesulfonyl fluoride hydrochloride (Pefabloc; inhibitor of serine proteases); all reagents were from Sigma-Aldrich. All inhibitors were added to the cell suspensions to a final concentration of $10 \mathrm{~m} M$. After incubation for $2 \mathrm{~h}$ at $37^{\circ} \mathrm{C}$, the cell suspensions were mixed with the substrate solutions (Na-caseinate or denatured whey proteins) in a $1: 1$ (vol/vol) ratio, incubated at $42^{\circ} \mathrm{C}$ for $24 \mathrm{~h}$, and analyzed by SDS-PAGE.

\section{Kinetics of Proteolysis}

The kinetics of hydrolysis of Na-caseinate or denatured whey proteins by the selected LAB strain was studied in the nonproliferative cell system, at $\mathrm{pH}$ 6.5. The cell suspensions were mixed with protein substrates $(1: 1, \mathrm{vol} / \mathrm{vol})$ and incubated at $42^{\circ} \mathrm{C}$. Samples were collected after $3,6,9$, or $24 \mathrm{~h}$ of incubation and analyzed by SDS-PAGE for the observation of proteins hydrolysis and peptide formation.

\section{Proteins Hydrolysis and Peptide Profiles Assessment in RP-HPLC}

The extension of protein hydrolysis and the profile of peptides generated by the treatment of Na-caseinate or denatured whey proteins with the cell suspension of selected proteolytic LAB strain were analyzed by RP-HPLC. The proteolysis was carried out in the nonproliferative cell system at $\mathrm{pH}$ 6.5. The cell suspension was mixed with the substrate solutions $(1: 1, \mathrm{vol} / \mathrm{vol})$ and incubated at $42^{\circ} \mathrm{C}$ for $24 \mathrm{~h}$. Before injection in the column, the sample was mixed $(1: 1, \mathrm{vol} / \mathrm{vol})$ with $9 M$ urea (Acros Organics, Geel, Belgium) and centrifuged $\left(12,000 \times g\right.$ for $5 \mathrm{~min}$ at $\left.4^{\circ} \mathrm{C}\right)$ to remove the cells. The supernatant was injected in a $\mathrm{C}_{18}$ symmetry column $(2.1 \times 150 \mathrm{~mm}$, Waters, Milford, MA) and the analysis was carried out in a HPLC System Alliance (Waters), under the following conditions: flow rate, $0.2 \mathrm{~mL} / \mathrm{min}$; solvent A, water $94.95 \%$, acetonitrile $5.0 \%$, trifluoroacetic acid (TFA) $0.05 \%$ ( $\mathrm{vol} / \mathrm{vol} / \mathrm{vol}$ ); solvent $\mathrm{B}$, isopropanol $19.97 \%$, acetonitrile $80 \%$, TFA $0.03 \%$ (vol/ vol/vol); all reagents were from Carlo Erba Reagents. Elution was performed with a linear gradient of solvent
$\mathrm{B}$, ranging from 0 to $100 \%$. Detection was performed at $220 \mathrm{~nm}$, using a photodiode array detector (model 996, Waters), and the data were analyzed by using Empower software (Waters). The obtained protein and peptide profiles were compared with those obtained for control protein fractions.

\section{RESULTS AND DISCUSSION}

A collection of 200 isolates showed potential production of proteolytic enzymes. Sixty-five isolates were confirmed as LAB and selected for confirmation of proteolytic activity in skim milk. Of these, 51 isolates were able to hydrolyze at least one milk protein fraction, indicated by reduced color intensity of the bands in SDS-PAGE and by appearance of new bands with lower molecular weight compared with the control (data not shown).

The RAPD profiles of the 51 proteolytic isolates indicated that they belonged to 9 strains. Using primers M13 and E2, 3 and 6 different profiles were obtained, respectively, whereas amplification with primer E1 generated identical fragments for all isolates. One isolate of each strain was submitted to amplification and sequencing of $16 \mathrm{~S}$ rDNA, which resulted in $99 \%$ identity with the 16S rRNA sequences reported for Enterococcus faecalis strains, such as Ent. faecalis S4-15 (accession number: KC478511.1), Ent. faecalis KDLLL4-1 (accession number: KC454284.1), and Ent. faecalis CNM506 12 (accession number: KC699226.1), indicating that all 9 isolates were Ent. faecalis. These results agree with literature data in which Enterococcus is the most common LAB genus in raw milk microbiota, with Ent. faecalis and Ent. faecium being the most common enterococcal species in milk and dairy products (Quigley et al., 2013). Enterococcus is known to possess a very efficient proteolytic system, contributing to the development of sensorial characteristics in cheeses and other fermented dairy products (Franz et al., 1999; Foulquié Moreno, et al., 2006; Serio et al., 2010; Ahmadova et al., 2011).

The PCR assays indicated that the 9 isolates possessed the genes asa1 (aggregation substance), ace (adhesin of collagen protein), and gelE (gelatinase), and all were negative for the genes esp (enterococcal surface protein), efaAfs (cell wall adhesin), cylA (cytolysin A), and $c y l B$ (cytolysin B). Checking for these virulence genes is of utmost importance as enterococci can be the causative agents of infections in hospitalized patients and nosocomial bloodstream infections (Vankerckhoven et al., 2008). Moreover, the investigation of virulence factors in LAB for food applications is mandatory as they may contain several determinants of pathogenic- 
ity received from other bacterial species via horizontal gene transfer. Several virulence factors were already described in Enterococcus. Cytolysin remains one of the most important and studied virulence traits attributed to enterococci, and the molecular screening of cyl genes is recommended for hemolytic and nonhemolytic strains (Morandi et al., 2013). It is important to note that none of the isolates studied here presented the genes encoding cytolysins A and B. However, 2 genes encoding adhesion-associated proteins were found: asa1 and ace. Other authors have reported a high incidence of asa1 and ace in Ent. faecalis strains isolated from dairy products, although none of these genes has been clearly and unequivocally associated with clinical isolates (Martín-Platero et al., 2009; Ahmadova et al., 2011). Another virulence gene found in all strains was gelE, which encodes a zinc metalloprotease that has been shown to contribute to Ent. faecalis virulence in some animal models. However, the presence of the gelE gene does not imply that the strain will express gelatinase activity (Eaton and Gasson, 2001; Qin et al., 2001; Semedo et al., 2003). The gelE gene is frequently found in proteolytic strains isolated from dairy and meat products (Lopes et al., 2006; Ahmadova et al., 2011).

Tests performed with Na-caseinate or denatured whey proteins indicated that the 9 strains shared similar proteolytic activity, with the ability to hydrolyze both protein substrates, albeit to different extents. The highest proteolytic activity was observed against Nacaseinate fractions $\left(\beta-, \alpha_{\mathrm{S}^{-}}\right.$, and $\left.\alpha_{\mathrm{S}^{-}} \mathrm{CN}\right)$, whereas only weak activity was observed against the denatured whey proteins ( $\alpha$-LA and $\beta$-LG). Qualitative comparison of staining intensity of the bands indicated that Ent. faecalis VB63F was the most active strain.

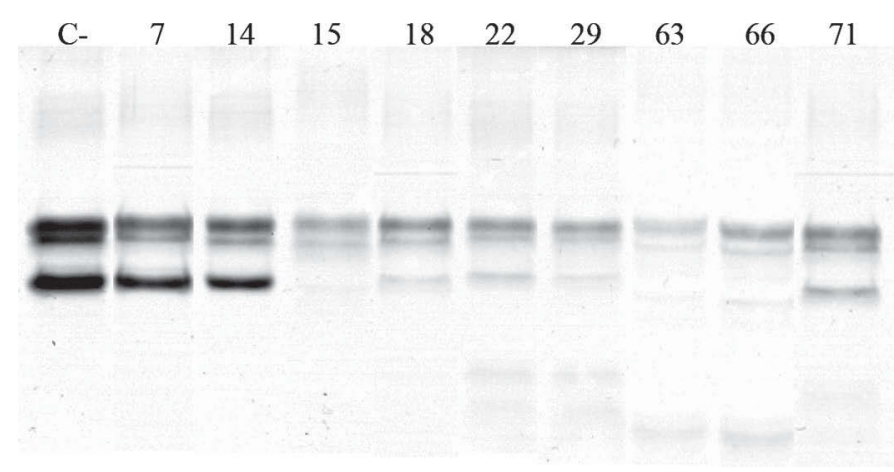

Figure 1. Sodium dodecyl sulfate-PAGE showing the Na-caseinate hydrolysis profiles caused by proteolytic strains $\left(37^{\circ} \mathrm{C}, 24 \mathrm{~h}, \mathrm{pH} 7.0\right)$. $\mathrm{C}$ - $=$ negative control (Na-caseinate only); lanes 7 to $71=$ test samples (Na-caseinate and the proteolytic strain).
All isolates displayed weak activity against of $\alpha-\mathrm{LA}$ and $\beta$-LG (data not shown). However, when tested for proteolysis of Na-caseinate, Ent. faecalis VB63F was the most active against $\beta-, \alpha_{\mathrm{S}^{-}}$, and $\alpha_{\mathrm{S}_{2}} \mathrm{CN}$ (Figure 1). This strain was considered the most active and was selected for characterization of proteolytic activity.

Hydrolysis of Na-caseinate and denatured whey proteins fractions was influenced by $\mathrm{pH}$ and temperature. Proteases produced by Ent. faecalis VB63F were more active at $42^{\circ} \mathrm{C}$ than at $30^{\circ} \mathrm{C}$ or $37^{\circ} \mathrm{C}$, for both protein substrates (Figures $2 \mathrm{~A}$ and $2 \mathrm{~B}$ ). When hydrolysis occurred at $30^{\circ} \mathrm{C}$, only the band corresponding to $\beta$-CN showed reduced staining intensity, whereas the bands representing $\alpha_{\mathrm{S}^{-}}$and $\alpha_{\mathrm{S}^{-}}$- $\mathrm{CN}$ remained unchanged and were equal to those of the negative control. The staining intensity of all bands representing $\mathrm{Na}$-caseinate was reduced at $37^{\circ} \mathrm{C}$, suggesting that $\beta-, \alpha_{\mathrm{S1}^{-}}$, and $\alpha_{\mathrm{S2}^{-}} \mathrm{CN}$ were at least partially hydrolyzed at this temperature. However, at $42^{\circ} \mathrm{C}$, the reduction in the staining intensity of the bands of Na-caseinate was stronger than that observed at $37^{\circ} \mathrm{C}$. Moreover, $\beta$ - and $\alpha_{S_{2}-} \mathrm{CN}$ were hydrolyzed completely, as no electrophoretic band could be detected. In all tested temperatures, new bands of low molecular weight appeared, indicating the release of small peptides. In the case of denatured whey proteins, no hydrolysis was observed at $30^{\circ} \mathrm{C}$ or $37^{\circ} \mathrm{C}$, and a slight reduction in the staining intensity of the bands was observed when the testes were carried out at $42^{\circ} \mathrm{C}$, indicating partial hydrolysis of these proteins. These results agree with what was found by El-Ghaish et al. (2010), who observed that the extent of hydrolysis of bovine milk proteins by different strains of Ent. faecalis was higher at $42^{\circ} \mathrm{C}$ than at other temperatures.

The $\mathrm{pH}$ did not influence the proteolytic activity of the proteases produced by Ent. faecalis VB63F (Figure $3 \mathrm{~A})$, as $\beta-, \alpha_{\mathrm{S}^{-}}$, and $\alpha_{\mathrm{S}^{-}} \mathrm{CN}$ were hydrolyzed at all tested $\mathrm{pH}$. However, the best results were observed at $\mathrm{pH}$ 6.5. All Na-caseinate fractions were intensively hydrolyzed at pH 6.0 and 7.0; however, $\alpha_{\mathrm{S1}_{1} \text {-casein was }}$ somewhat resistant. The casein electrophoretic bands disappeared at $\mathrm{pH} 6.5$, indicating total hydrolysis of $\beta$-, $\alpha_{\mathrm{S1}^{-}}$, and $\alpha_{\mathrm{S} 2^{-}} \mathrm{CN}$. In case of denatured whey proteins, the best results were obtained when proteolytic activity was tested at $\mathrm{pH} 6.5$ and $\mathrm{pH} 7.0$ (Figure 3B), when a reduction in the staining intensity of the bands representing $\alpha-L A$ and $\beta-L G$ was observed, indicating partial hydrolysis of these proteins. At pH 6.0, no hydrolysis was observed. Because $\mathrm{pH} 6.5$ yielded the best results for both Na-caseinate and denatured whey proteins, this $\mathrm{pH}$ was selected as the best one for the studies of the activity of the proteases produced by Ent. faecalis VB63F. Other authors also reported that proteolysis 

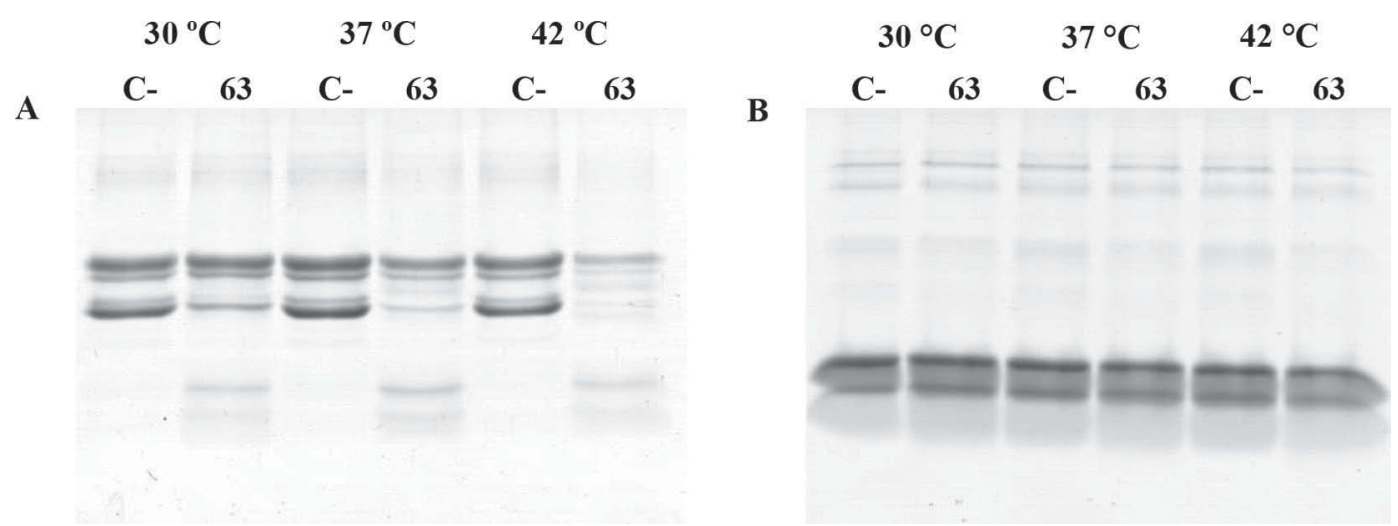

Figure 2. Sodium dodecyl sulfate-PAGE showing the hydrolysis profiles of Na-caseinate (A) and denatured whey proteins (B), caused by Enterococcus faecalis $\mathrm{VB} 63 \mathrm{~F}$ at $30^{\circ} \mathrm{C}, 37^{\circ} \mathrm{C}$, and $42^{\circ} \mathrm{C}(24 \mathrm{~h}, \mathrm{pH} 7.0)$. Lane $\mathrm{C}$ - = negative controls [Na-caseinate (A) or denatured whey proteins (B)]; lane $63=$ samples treated with Ent. faecalis VB63F.

of Ent. faecalis was more effective at $\mathrm{pH} 6.5$ or close to neutral (El-Ghaish et al., 2010; Ahmadova et al., 2011).

The metalloprotease inhibitor EDTA strongly suppressed the hydrolysis of both Na-caseinate and denatured whey proteins by Ent. faecalis VB63F (Figure $4 \mathrm{~A}$ and $\mathrm{B}$, respectively). Neither iodoacetic acid nor Pefabloc affected proteolytic activity, indicating that neither cysteine nor serine proteases were involved. Others studies have reported that strains of Ent. faecalis produce metalloproteases and, if other types of proteases were present, they played a minor role in the hydrolysis of milk protein fractions (El-Ghaish et al., 2010; Ahmadova et al., 2011).

Concerning the kinetics of proteolysis of $\beta-, \alpha_{\mathrm{S}^{-}}$, and $\alpha_{\mathrm{S}^{2}} \mathrm{CN}, \beta-\mathrm{LG}$, and $\alpha-\mathrm{LA}$ by Ent. faecalis VB63F, carried out under optimal conditions of $\mathrm{pH}$ and temperature, the extent of hydrolysis varied according to substrate (Figure 5A). $\beta$-Casein was the main protein targeted by the proteases of Ent. faecalis $\mathrm{VB} 63 \mathrm{~F}$ - the band corresponding to the native form disappeared completely from the gel in the first hours at $42^{\circ} \mathrm{C}$. The second target was $\alpha_{S_{2}} \mathrm{CN}$, which was completely hydrolyzed after $9 \mathrm{~h}$. At the end of the incubation period, the band representing the native form of $\alpha_{\mathrm{S1}^{-}} \mathrm{CN}$ was also greatly reduced. These results indicate that the proteolytic enzymes produced by Ent. faecalis VB63F have a strong activity against $\mathrm{Na}$-caseinate fractions of milk proteins. In case of denatured whey proteins (Figure 5B), hydrolysis occurred only after $24 \mathrm{~h}$ and the reduction in the staining intensity of the bands
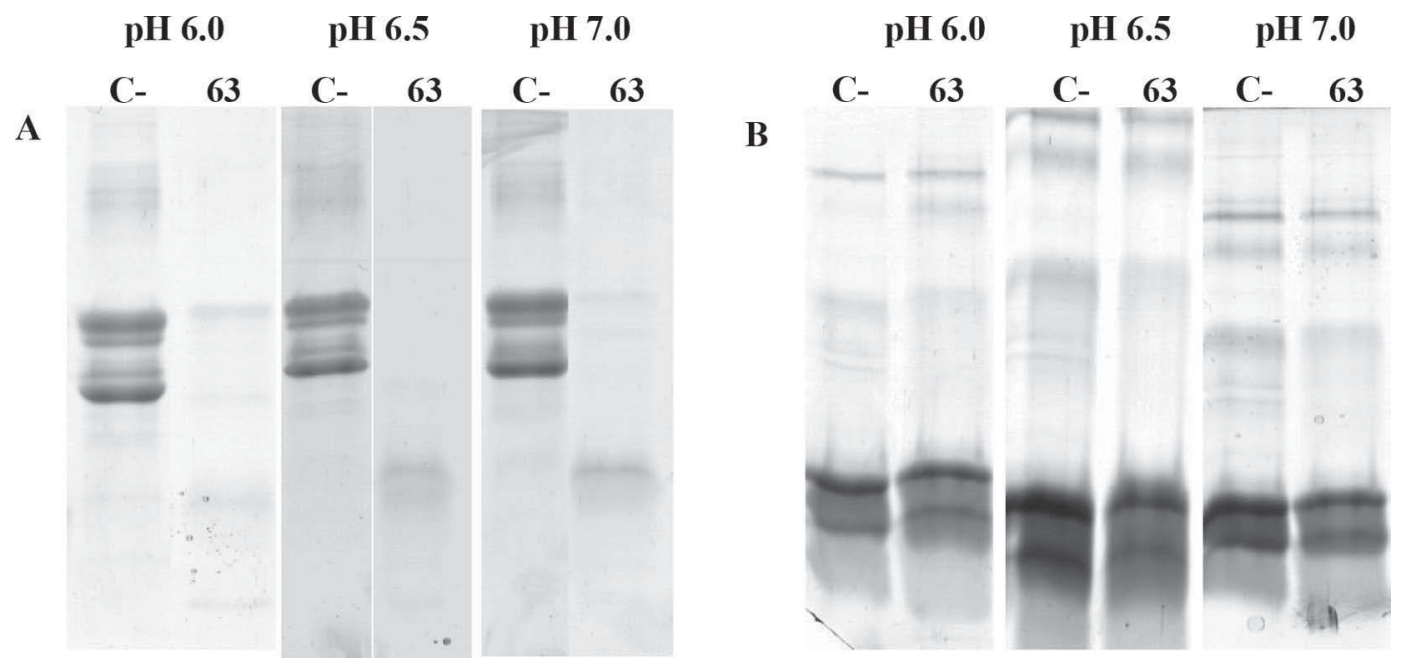

Figure 3. Sodium dodecyl sulfate-PAGE showing the hydrolysis profiles of Na-caseinate (A) and denatured whey proteins (B), caused by Enterococcus faecalis $\mathrm{VB} 63 \mathrm{~F}$ at $\mathrm{pH} 6.0,6.5$, and $7.0\left(37^{\circ} \mathrm{C}, 24 \mathrm{~h}\right)$. Lane C- = negative controls [Na-caseinate $(\mathrm{A})$ or denatured whey proteins (B)]; lane $63=$ samples treated with Ent. faecalis VB63F. 

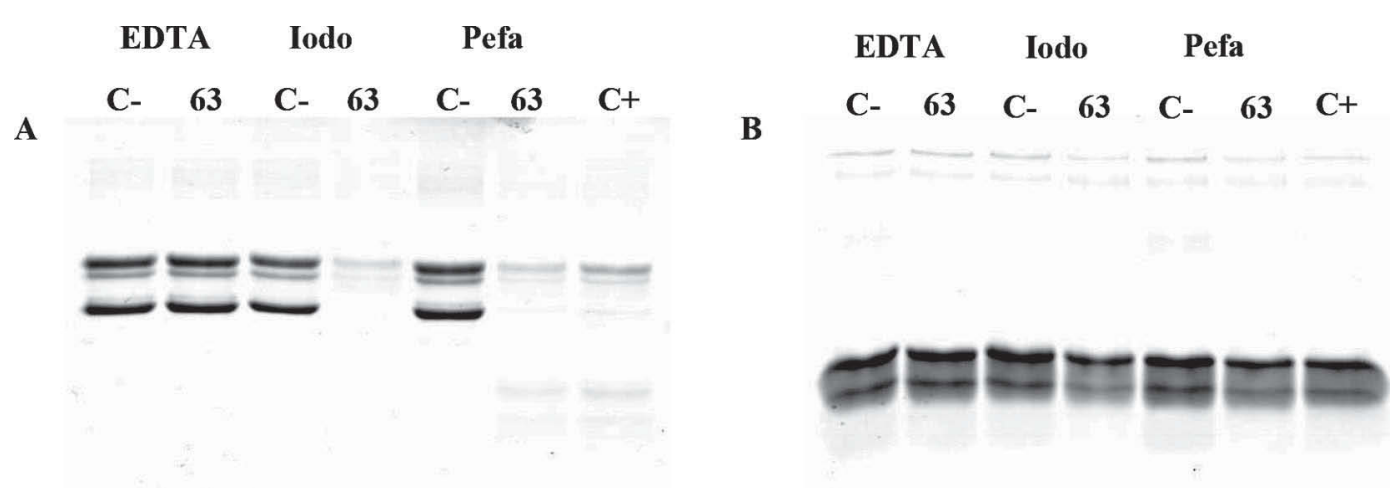

Figure 4. Sodium dodecyl sulfate-PAGE showing the hydrolysis profiles of Na-caseinate (A) and denatured whey proteins (B), caused by Enterococcus faecalis $\mathrm{VB} 63 \mathrm{~F}\left(42^{\circ} \mathrm{C}, 24 \mathrm{~h}, \mathrm{pH} 7.0\right)$ in the presence of protease inhibitors. C- = negative controls [Na-caseinate (A) and denatured whey proteins $(\mathrm{B})] ; \mathrm{C}+=$ positive control [Na-caseinate $(\mathrm{A})$ and denatured whey proteins $(\mathrm{B})$ inoculated with proteolytic strain]; lane $63=$ samples treated with Ent. faecalis VB63F; EDTA = metalloprotease inhibitor; Iodo = iodoacetic acid (cysteine protease inhibitor); Pefa = Pefabloc (serine protease inhibitor). All inhibitors were from Sigma-Aldrich (Munich, Germany).

corresponding to $\alpha$-LA and $\beta$-LG were weaker than those of Na-caseinate. These results suggest that the proteolytic enzymes produced by Ent. faecalis VB63F have poor activity against whey proteins and are only able to partially hydrolyze $\alpha-\mathrm{LA}$ and $\beta$-LG.

The HPLC analysis of Na-caseinate and whey protein fraction proteolysis by Ent. faecalis VB63F, after $24 \mathrm{~h}$ and under optimal conditions of $\mathrm{pH}$ and temperature, confirmed the results observed by SDS-PAGE (Figure $6 \mathrm{~A})$. The peaks representing the native forms of the caseins disappeared and smaller peaks appeared, suggesting the release of medium-sized, less-hydrophobic peptides. The HPLC profiles of denatured whey proteins showed that $\alpha-\mathrm{LA}$ and $\beta-\mathrm{LG}$ were still present in treated samples (Figure $6 \mathrm{~B}$ ), but the appearance of less-hydrophobic peaks suggested that whey proteins were partially hydrolyzed.

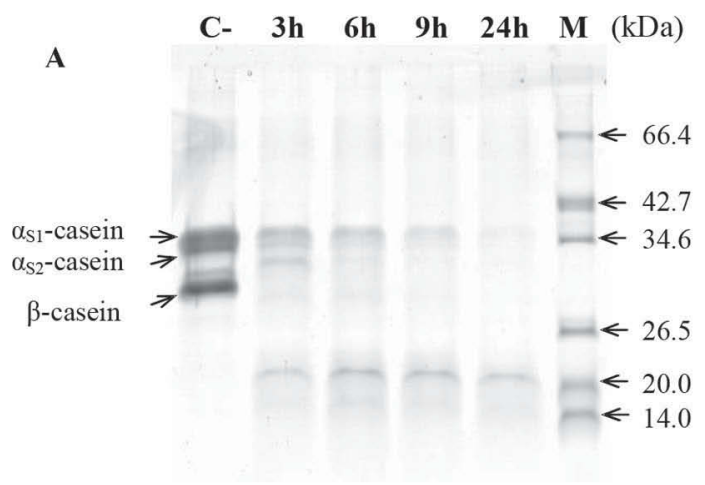

Our results indicate that Ent. faecalis $\mathrm{VB} 63 \mathrm{~F}$ has strong proteolytic activity against bovine caseins. Although $\beta-L G$ is recognized by many authors as the main allergen in bovine milk (Pescuma et al., 2012), caseins also play an important role in CMA development, because many allergic patients present casein-specific IgE (Docena et al., 1996; Bu et al., 2013). In addition, it has been demonstrated that the persistence of milk allergy is associated with the presence of specific $\operatorname{IgE}$ that recognize linear epitopes (present in casein fractions), rather than the conformational epitopes that are present in $\beta$-LG (Vila et al., 2001; Järvinen et al., 2002). Järvinen et al. (2002), studying persistence of cow milk allergy, noted that patients with symptoms of persistent milk allergy recognize a greater number of sequential (linear) milk-protein epitopes on $\alpha_{\mathrm{S}_{1}}$ and $\beta-\mathrm{CN}$, compared with patients who develop clinical

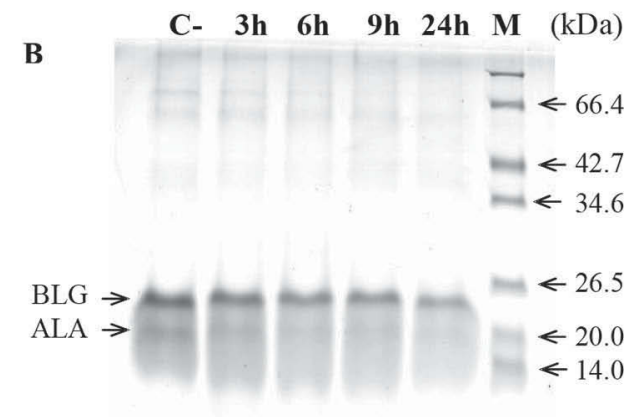

Figure 5. Sodium dodecyl sulfate-PAGE showing the hydrolysis profiles of Na-caseinate (A) and denatured whey proteins (B), caused by Enterococcus faecalis $\mathrm{VB} 63 \mathrm{~F}$ after $3,6,9$, and $24 \mathrm{~h}$ at $42^{\circ} \mathrm{C}(\mathrm{pH} 6.5)$. C- = negative controls [Na-caseinate (A) and denatured whey proteins (B)]; $\mathrm{M}=$ molecular weight marker; $\mathrm{BLG}=\beta$-LG, ALA $=\alpha-\mathrm{LA}$. 

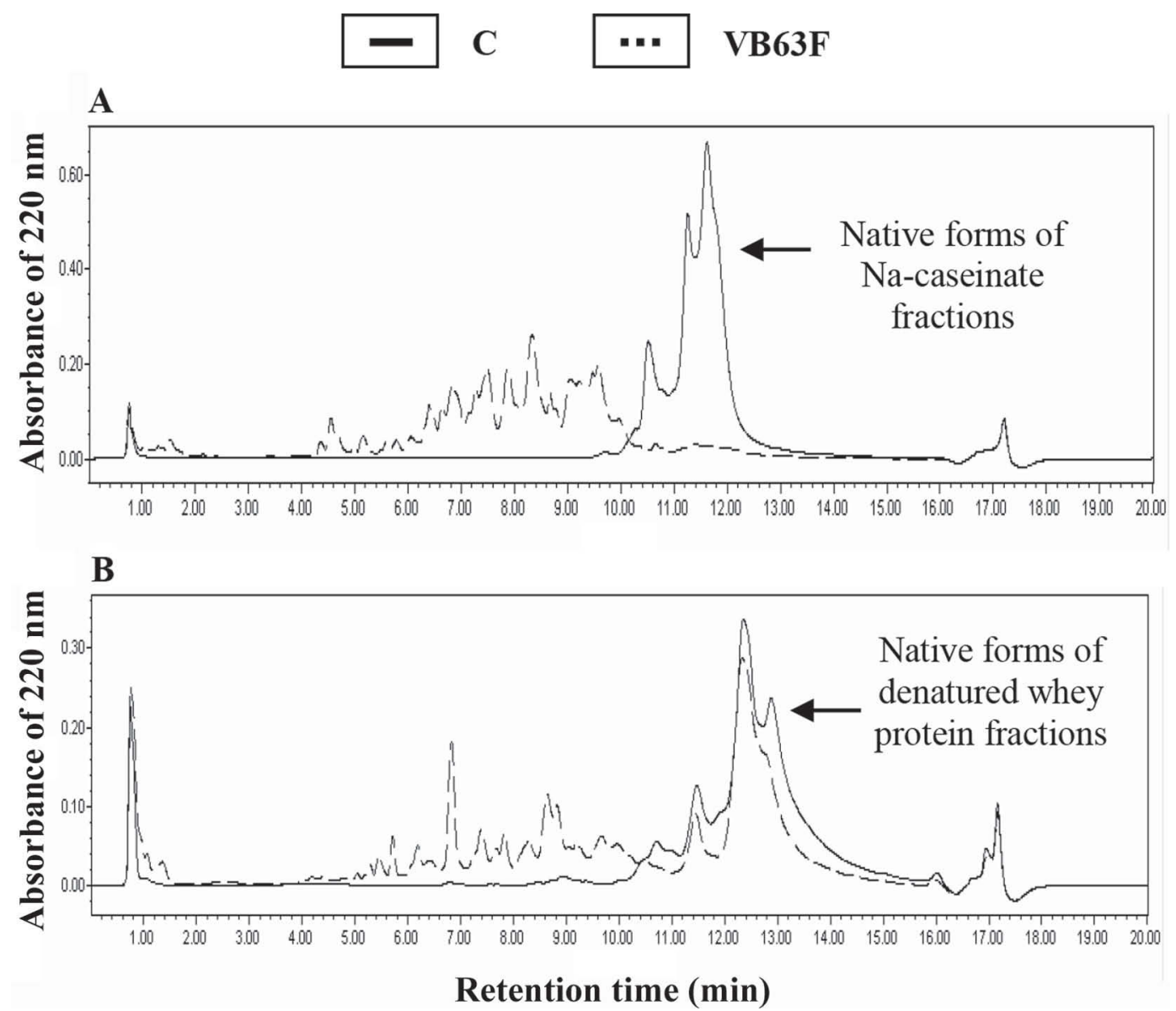

Figure 6. Reverse phase-HPLC profiles of milk proteins resulting from hydrolysis of Na-caseinate (A) and denatured whey proteins (B), caused by Enterococcus faecalis VB63F. C = negative control (not treated with Enterococcus faecalis VB63F); VB63F = test samples (treated with Enterococcus faecalis VB63F).

tolerance to milk. Similar results were reported by Sicherer and Sampson (1999). Those authors found that patients with persistent allergy (over 9 yr of age) had significantly elevated levels of casein-specific IgE. Thus, the study of new proteolytic LAB strains able to hydrolyze the casein fractions of milk could help reduce the allergenicity of bovine milk proteins and provide interesting data, which could lead to the development of new hypoallergenic dairy products.

\section{CONCLUSIONS}

Our data indicate that Ent. faecalis VB63F has good proteolytic activity against caseins. This interesting trait, combined with absence of virulence factors, raise the possibility of applying this strain to reduce the allergenicity of bovine milk proteins. Further examination of the specific IgE capability to bind the Na-caseinate hydrolysates will indicate the level of reduction in the immunoreactivity of these milk protein fractions.

\section{ACKNOWLEDGMENTS}

The authors thank Coordenação de Aperfeiçoamento de Pessoal de Nível Superior (CAPES; Brasilia, Brazil) and Comité Français d'Evaluation de la Coopération Universitaire avec le Brésil (COFECUB; Villetaneuse, France), Brazilian Research Council (CNPq; Brasilia, Brazil), and Sao Paulo Research Foundation (FAPESP; São Paulo, Brazil) for financial support and scholarship to author V. Biscola.

\section{REFERENCES}

Ahmadova, A., S. Dimov, I. Ivanova, Y. Choiset, J. M. Chobert, A. Kuliev, and T. Haertlé. 2011. Proteolytic activities and safety of use of enterococci strains isolated from traditional Azerbaijani dairy products. Eur. Food Res. Technol. 233:131-140.

Ben Omar, N., A. Castro, R. Lucas, H. Abriouel, N. M. Yousif, C. M. Franz, W. H. Holzapfel, R. Pérez-Pulido, M. Martínez-Cañamero, and A. Gálvez. 2004. Functional and safety aspects of enterococci isolated from different Spanish foods. Syst. Appl. Microbiol. $27: 118-130$ 
Bertrand-Harb, C., E. V. Ivanova, M. Dalgalarrondo, and T. Haertlé. 2003. Evolution of $\beta$-globulin and $\alpha$-lactalbumin during yogurt fermentation. Int. Dairy J. 13:39-45.

Bu, G., Y. Luo, F. Chen, K. Liu, and T. Zhu. 2013. Milk processing as a tool to reduce cow's milk allergenicity: A mini-review. Dairy Sci. Technol. 93:211-223.

Bu, G., Y. Luo, Y. Zhang, and F. Chen. 2010. Effects of fermentation by lactic acid bacteria on the antigenicity of bovine whey proteins. J. Sci. Food Agric. 90:2015-2020.

Claeys, W. L., S. Cardoen, G. Daube, J. De-Block, K. Dewettinck, K. Dierick, L. De-Zutter, A. Huyghebaert, H. Imberechts, P. Thiange, Y. Vandenplans, and L. Herman. 2013. Raw or heated cow milk consumption: Review of risks and benefits. Food Contr. 31:251262.

Cocco, R. R., K. M. Jarvinen, H. A. Sampson, and K. Beyer. 2003. Mutational analysis of major, sequential IgE-binding epitopes in $\alpha_{\mathrm{S} 1}$-casein, a major cow's milk allergen. J. Allergy Clin. Immunol. 112:433-437.

Docena, G. H., R. Fernandez, F. G. Chirdo, and C. A. Fossati. 1996. Identification of casein as the major allergenic and antigenic protein of cow's milk. Allergy 51:412-416.

Eaton, T. J., and M. J. Gasson. 2001. Molecular screening of Enterococcus virulence determinants and potential for genetic exchange between food and medical isolates. Appl. Environ. Microbiol. 67:1628-1635.

El-Ghaish, S., A. Ahmadova, I. Hadji-Sfaxi, K. E. El-Mecherfi, I. Bazukyan, Y. Choiset, H. Rabesona, M. Sitohy, Y. G. Popov, A. A. Kuliev, F. Mozzi, J. M. Chobert, and T. Haertlé. 2011. Potential use of lactic acid bacteria for reduction of allergenicity and for longer conservation of fermented foods. Trends Food Sci. Technol. 22:509-516.

El-Ghaish, S., M. Dalgalarrondo, Y. Choiset, M. Sitohy, I. Ivanova, T. Haertlé, and J. M. Chobert. 2010. Screening of strains of lactococci isolated from Egyptian dairy products for their proteolytic activity. Food Chem. 120:758-764.

El-Mecherfi, K.E., D. Saidi, O. Kheroua, G. Boudraa, M. Touhami, O. Rouaud, S. Curet, Y. Choiset, H. Rabesona, J. M. Chobert, and T. Haertlé. 2011. Combined microwave and enzymatic treatments of beta-lactoglobulin and bovine whey proteins, and their effect on the IgE immunoreactivity. Eur. Food Res. Technol. 233:859-867.

Feldman, M. F., and J. A. Bird. 2014. Oral immunotherapy for food allergy, ready for prime time? Heated egg and milk. Curr. Allergy Asthma Rep. 14:436. http://dx.doi.org/10.1007/s11882-014-04366.

Fira, D., M. Kojic, A. Banina, I. Spasojevic, I. Strahinic, and L. Topisirovic. 2001. Characterization of cell envelope-associated proteinases of thermophilic lactobacilli. J. Appl. Microbiol. 90:123-130.

Foulquié Moreno, M. R., P. Sarantinopoulos, E. Tsakalidou, and L. De Vuyst. 2006. The role and application of enterococci in food and health. Int. J. Food Microbiol. 106:1-24.

Franz, C. M., W. H. Holzapfel, and M. E. Stiles. 1999. Enterococci at the crossroads of food safety? Int. J. Food Microbiol. 47:1-24.

Gaudin, J. C., H. Rabesona, Y. Choiset, G. Yeretssian, J. M. Chobert, V. Sakanyan, M. Drouet, and T. Haertlé. 2008. Assessment of the immunoglobulin E-mediated immune response to milk-specific proteins in allergic patients using microarrays. Clin. Exp. Allergy 38:686-693.

Järvinen, K. M., K. Beyer, L. Vila, P. Chatchatee, P. J. Busse, and H. A. Sampson. 2002. B-cell epitopes as a screening instrument for persistent cow's milk allergy. J. Allergy Clin. Immunol. 110:293297.

Kirilov, N., S. Dimov, M. Dalgalarrondo, T. Ignatova, S. Kambarev, S. Stoyanovski, S. Danova, I. Iliev, T. Haertlé, J. M. Chobert, and I. Ivanova. 2011. Characterization of enterococci isolated from homemade Bulgarian cheeses and katuk. Eur. Food Res. Technol. 233:1029-1040.

Kleber, N., U. Weyrich, and J. Hinrichs. 2006. Screening for lactic acid bacteria with potential to reduce antigenic response of $\beta$-lactoglobulin in bovine skim milk and sweet whey. Innov. Food Sci. Emerg. Technol. 7:233-238.
Koch, A., S. Brandenburger, S. Türpe, and M. Birringer. 2014. The need for a legal distinction of nutraceuticals. Food Nutr. Sci. 5:905-913.

Laemmli, U. K. 1970. Cleavage of structural proteins during the assembly of the head of bacteriophage T4. Nature 227:680-685.

Lopes, M. F. S., A. P. Simões, R. Terneiro, J. J. F. Marques, and M. T. B. Crespo. 2006. Activity and expression of a virulence factor, gelatinase, in dairy enterococci. Int. J. Food Microbiol. 112:208-214.

Lozo, J., I. Strahinic, M. Dalgalarrondo, J. M. Chobert, T. Haertlé, and L. Topisirovic. 2011. Comparative analysis of $\beta$-casein proteolysis by PrtP proteinase from Lactobacillus paracasei ssp. paracasei BGHN14, PrtR proteinase from Lactobacillus rhamnosus BGT10 and PrtH from Lactobacillus helveticus BGRA43. Int. Dairy J. 21:863-868.

Martín-Platero, A. M., E. Valdivia, M. Maqueda, and M. MartínezBueno. 2009. Characterization and safety evaluation of enterococci isolated from Spanish goats' milk cheeses. Int. J. Food Microbiol. 132:24-32.

Morandi, S., Y. Silvetti, and M. Brasca. 2013. Biotechnological and safety characterization of Enterococcus lactis, a recently described species of dairy origin. Antonie Van Leeuwenhoek 103:239-249.

Mozzi, F., M. E. Ortiz, J. Bleckwedel, L. de Vuyst, and M. Pescuma. 2013. Metabolomics as a tool for the comprehensive understanding of fermented and functional foods with lactic acid bacteria. Food Res. Int. 54:1152-1161.

Natale, M., C. Bisson, and G. Monti. 2004. Cow's milk allergens identification by two-dimensional immunoblotting and mass spectrometry. Mol. Nutr. Food Res. 48:363-369.

Pailin, T., D. H. Kang, K. Schmidt, and D. Y. C. Fung. 2001. Detection of extracellular bound proteinase in EPS-producing lactic acid bacteria cultures on skim milk agar. Lett. Appl. Microbiol. $33: 45-49$.

Passalacqua, G., M. Landi, and G. B. Pajno. 2012. Oral immunotherapy for cow's milk allergy. Curr. Opin. Allergy Clin. Immunol. 12:271-277.

Peñas, E., G. Prestamo, M. L. Baeza, M. I. Martinez-Molero, and R. Gomez. 2006. Effect of combined high pressure and enzymatic treatment on the hydrolysis and immuno-reactivity of dairy whey proteins. Int. Dairy J. 16:831-839.

Pescuma, M., E. M. Hebert, E. Bru, G. F. Valdez, and F. Mozzi. 2012. Diversity in growth and protein degradation by dairy relevant lactic acid bacteria species in reconstituted whey. J. Dairy Res. 79:201-208.

Pescuma, M., E. M. Hebert, T. Haertlé, J. M. Chobert, F. Mozzi, and G. F. Valdez. 2015. Lactobacillus delbrueckii ssp. bulgaricus CRL454 cleaves allergenic peptides of $\beta$-lactoglobulin. Food Chem. 170:407-414

Pescuma, M., E. M. Hebert, F. Mozzi, and G. F. Valdez. 2010. Functional fermented whey-based beverage using lactic acid bacteria. Int. J. Food Microbiol. 141:73-81.

Pescuma, M., E. M. Hebert, H. Rabesona, M. Drouet, Y. Choiset, T. Haertlé, F. Mozzi, G. F. de Valdez, and J. M. Chobert. 2011. Proteolytic action of Lactobacillus delbrueckii ssp. bulgaricus CRL656 reduces antigenic response to bovine $\beta$-lactoglobulin. Food Chem. 127:487-492.

Qin, X., K. V. Singh, G. M. Weinstock, and B. E. Murray. 2001. Characterization of $f s r$, a regulator controlling expression of gelatinase and serine protease in Enterococcus faecalis OG1RF. J. Bacteriol. 183:3372-3382.

Quigley, L., O. O'Sullivan, C. Stanton, T. P. Beresford, R. P. Toss, G. F. Fitzgerald, and P. D. Cotter. 2013. The complex microbiota of raw milk. FEMS Microbiol. Rev. 37:664-698.

Restani, P., C. Ballabio, C. Loenzo, S. Tripodi, and A. Fiocchi. 2009. Molecular aspects of milk allergens and their role in clinical events. Anal. Bioanal. Chem. 395:47-56.

Rossetti, L., and G. Giraffa. 2005. Rapid identification of dairy lactic acid bacteria by M13-generated, RAPD-PCR fingerprint databases. J. Microbiol. Methods 63:135-144.

Semedo, T., M. Almeida-Santos, P. Martins, M. F. Silva-Lopes, J. J. Figueiredo-Marques, R. Tenreiro, and M. T. Barreto-Crespo. 2003. 
Comparative study using type strains and clinical and food isolates to examine hemolytic activity and occurrence of the cyl operon in enterococci. J. Clin. Microbiol. 41:2569-2576.

Serio, A., C. Chaves-López, A. Paparella, and G. Suzzi. 2010. Evaluation of metabolic activities of enterococci isolated from Pecorino Abruzzese cheese. Int. Dairy J. 20:459-464.

Shankar, N., C. V. Lockatell, A. S. Baghayan, C. Drachenberg, M. S. Gilmore, and D. E. Johnson. 2001. Role of Enterococcus faecalis surface protein esp in the pathogenesis of ascending urinary tract infection. Infect. Immun. 69:4366-4372.

Sicherer, S. H., and H. A. Sampson. 1999. Cow's milk protein-specific IgE concentrations in two age groups of milk-allergic children and in children achieving clinical tolerance. Clin. Exp. Allergy 29:507512

Taheri-Kafrani, A., J. C. Gaudin, H. Rabesona, C. Nioi, D. Agarwal, M. Drouet, J. M. Chobert, A. K. Bordbar, and T. Haertlé. 2009. Effects of heating and glycation of $\beta$-lactoglobulin on its recognition by IgE of sera from cow milk allergy patients. J. Agric. Food Chem. 57:4974-4982.
Vankerckhoven, V., G. Huys, M. Vancanneyt, C. Vael, I. Klare, M. Romond, J. M. Entenza, P. Moreillon, R. D. Wind, J. Knol, E. Wiertz, B. Pot, E. E. Vaughan, G. Kahlmeter, and H. Goossens. 2008. Biosafety assessment of probiotics used for human consumption: recommendations from the EU-PROSAFE project. Trends Food Sci. Technol. 19:102-114.

Vankerckhoven, V., T. van Autgaerden, C. Vael, C. Lammens, S. Chapelle, R. Rossi, D. Jabes, and H. Goznes. 2004. Development of a multiplex PCR for the detection of asa1, gelE, cylA, esp, and hyl genes in Enterococci and survey for virulence determinants among European hospital isolates of Enterococcus faecium. J. Clin. Microbiol. 42:4473-4479.

Vila, L., K. Beyer, K. M. Jarvinen, P. Chatchatee, L. Bardina, and H. A. Sampson. 2001. Role of conformational and linear epitopes in the achievement of tolerance in cow's milk allergy. Clin. Exp. Allergy 31:1599-1606.

Weisburg, W. G., S. M. Barns, D. A. Pelletier, and D. J. Lane. 1991. $16 \mathrm{~S}$ ribosomal DNA amplification for phylogenetic study. J. Bacteriol. 173:697-703. 